DOI: $10.14451 / 2.157 .24$

\title{
РЕШЕНИЕ НЮРНБЕРГСКОГО МЕЖДУНАРОДНОГО ВОЕННОГО ТРИБУНАЛА КАК ПРАВОВОЕ ОСНОВАНИЕ КРИМИНАЛИЗАЦИИ ПРЕСТУПЛЕНИЙ ПРОТИВ ЧЕЛОВЕЧНОСТИ
}

\author{
(c) 2021 Радошнова Наталия Валерьевна \\ кандидат юридических наук, доцент кафедры уголовного права и уголовного процесса \\ Санкт-Петербургский государственный экономический университет, Россия, Санкт-Петербург \\ E-mail: radoshnova@bk.ru \\ (c) 2021 Варфоломеева Татьяна Валерьевна \\ бакалавр, юридический факультет \\ Санкт-Петербургский государственный экономический университет, Россия, Санкт-Петербург \\ E-mail: varfotatyana@yandex.ru \\ (c) 2021 Карлик Софья Михайловна \\ бакалавр, юридический факультет \\ Санкт-Петербургский государственный экономический университет, Россия, Санкт-Петербург \\ E-mail: soniakarlik14@gmail.com
}

Актуальность настоящей статьи даже не в том, что она публикуется в год 80-летия с начала Великой Отечественной Войны, а, в первую очередь, в нарастающем коме попыток переписать историю Великой победы и нивелировать её значение для человечества, уйти от криминальной сущности нацизма и его последствий. Именно итоги Нюрнбергского Международного Военного Трибунала послужили основанием для криминализации в уголовном праве многих стран преступлений против человечности. В российском законодательстве ответственность за такие преступления законодатель поместил в отдельный раздел Уголовного Кодекса Российской Федерации - Раздел XII. Преступления против мира и человечества.

Ключевые слова: Нюрнбергский процесс, Международный Военный трибунал, преступления против человечности, криминализация преступлений военного времени

В этом году исполнилось 76 лет со дня победы России над фашистской Германией, но, несмотря на это, мы каждый год вспоминаем, какой ценой была завоевана эта великая победа. Любые события прошлого, оставаясь в памяти потомков, могут быть прочитаны по-разному: и как урок, помогающий избежать чудовищных ошибок прошлого, и как образец мужества и героизма, на который следует равняться.

Наша статья посвящается одному аспекту морфологического генезиса юриспруденции, напрямую связанному с событиями военных и послевоенных лет: мы попытаемся проследить основные вехи развития законодательства о преступлениях против человечности - от Нюрнбергского Международного Военного Трибунала и до настоящего времени.

Задолго до начала Великой Отечественной Войны, в 1928 г. в Париже, пятнадцатью ведущими мировыми державами был подписан Пакт Бриана-Келлога, в котором провозглашался от- каз от войны и который рассматривался в качестве орудия национальной политики [1]. В числе этих стран была и Германия, которая, как показали дальнейшие события, условия Пакта выполнять не собиралась.

Война была развязана фашистской Германией, но еще до ее окончания стало понятно, что нацистским преступникам не удастся избежать ответственности за свои зверские деяния. Помимо погибших на фронтах в годы войны, огромным были потери среди мирного населения: только в концентрационном лагере в Освенциме за время войны было расстреляно, повешено и умерщвлено в газовых камерах более 4 млн. человек из разных стран Европы и СССР.

Решение о создании Международного Военного Трибунала для осуждения военных преступников европейских стран «оси» было принято представителями СССР, США, Великобритании и Франции 08.08.1945 г. в Лондоне вместе с Уставом Международного Военного 
Трибунала, определившем порядок организации самого Трибунала и принципы его работы. При работе над Уставом возникало множество трудностей, так как главные партнеры антигитлеровской коалиции имели разные правовые системы (англосаксонскую, континентальную и социалистическую). Тем не менее, было найдено приемлемое для всех решение и сформирован уникальный процессуальный инструмент, который оказался действенным.

Учрежденный Международный Военный Трибунал имел право «судить и наказывать лиц, которые, действуя в интересах европейских стран «оси» индивидуально или в качестве членов организаций, совершили любое из следующих преступлений:

a) преступления против мира;

б) военные преступления;

в) преступления против человечности.

Международным трибуналом были приговорены к смертной казни через повешение 12 ближайших сообщников Гитлера: Г.Геринг, И.Риббентроп, В.Кейтель, Э.Кальтенбруннер, А.Розенберг, Г.Франк, В.Фрик, Ю.Штрейхер, Ф. Заукель, А.Йодль, А. Зейсс-Инкварт и М.Борман (заочно). К тюремному заключению было приговорено 7 человек, из которых 3 к пожизненному - Р. Гесс, В. Функ и Э. Редер, остальные к разным срокам: К. Дениц (к 10 годам лишения свободы), Б.Ширах (к 20 годам лишения свободы), А.Шпеер (к 20 годам лишения свободы), президент тайного совета К.Нейрат (к 15 годам лишения свободы).

Подсудимый Крупп фон Болен унд Гальбах, крупнейший промышленник и организатор перевооружения германской армии, был признан врачебной комиссией психически-нездоровым, в результате чего его дело было приостановлено Трибуналом.

Следует отметить, что в Нюрнберге Международный Военный Трибунал осудил далеко не всех немецких военных преступников. Благодаря содействию нескольких западных держав и США многие из них остались безнаказанными. Но и из тех, кто все-таки оказался на скамье подсудимых, не все были осуждены. Был оправдан Я.Шахт, который являлся президентом Рейхсбанка и министром без портфеля; Ф.Папен, посол Германии в Турции; упономоченный по политическому радиовещанию Г. Фриче. Также следует отметить, что генеральный штаб, и высшее командование германских вооружен- ных сил, по мнению Трибунала, не были преступными организациями.

Нюрнбергский Международный Военный Трибунал начался 20.11.1945 г. и продолжался до 01.10.1946 г. В рамках процесса было проведено 403 заседания, заслушано 166 свидетелей, изучены сотни тысяч письменных показаний и документов. Говоря о доказательствах, предъявленных суду, следует обратиться к словам выдающегося американского юриста Р.Джексона, возглавлявшего обвинение от США, который в своей речи указал на ужасающий и ошеломляющий характер доказательств, на то, что после их предъявления, подсудимым останется возможность разве что отрицать свою вину и говорить о незнании того, что творилось в нацистской Германии. Одним из таких доказательств в трибунале была демонстрация документального фильма о преступлениях нацистов в концлагерях, которой вызвал у подсудимых абсолютно разные эмоции: В.Функ (президент Рейсбанка) рыдал, в то время как Р.Гесс (заместитель фюрера в НСДАП) говорил, что не верит во все показанное в фильме.

Нюрнбергский процесс заставил задуматься мировое сообщество о легальной криминализации преступлений против человечества. Генеральная ассамблея ООН Резолюцией от 11.12.1949 г. подтвердила принципы Нюрнбергского трибунала, признав агрессивную войну, военные преступления и преступления против человечества - тягчайшими международными преступлениями.

В 1948 г. принимается Конвенция о предупреждении геноцида и наказании за него [4]. Через 20 лет после этого, в 1968 г. принимается еще одна конвенция, связанная с военными преступлениями, а именно Конвенция о неприменимости срока давности к военным преступлениям и преступлениям против человечества [5].

В 1973 г. принимаются Принципы международного сотрудничества в отношении обнаружения, ареста, выдачи и наказания лиц, виновных в военных преступлениях и преступлениях против человечества [6].

Важным событием для международного сообщества стало создание Гаагского международного уголовного суда (далее по тексту - Гаагский МУС) в 1998 году. МУС стал первым постоянным действующим органом международной уголовной юстиции, который занимается преследованием лиц, обвиняемых в геноциде, военных 
преступлениях, преступлениях против человечности. Первое решение, вынесенное данным судом, заключалось в признании виновным военачальника из Демократической республики Конго Томаса Лубангу Дьило в привлечении на военную службу и использовании в военных действиях детей в пятилетним конфликте в Конго (1998-2000 гг.) [14]. Тем не менее, несмотря на значимость подобного органа международной юстиции, в решениях Гаагского суда в последние годы стали просматриваться определенная политическая направленность, что не всегда полезно для объективности решений.

Помимо постоянно действующего органа такого, как Гаагский МУС, история знает и случаи создания временных судебных органов, к числу которых относится и Нюрнбергский трибунал. Так, в 1994 г. был учрежден Международный трибунал по Руанде для расследования преступлений лиц, ответственных за геноцид, совершенный как на территории Руанды, так и на территории соседних государств в период с 1 января по 31 декабря 19994 г. Всего по делам трибунала проходило 93 обвиняемых, одним из которых был бывший полковник армии Руанды Теонесте Багасора. В 2012 г. он был приговорен к пожизненному заключению за организацию ополчения, участниками которого был народ хуту (господствовавшей этническая группа) под названием «Интерахамве», разработке и осуществление плана геноцида, в результате чего было умерщвлено более 800 тыс. человек из народности тутси [13].

Начиная с 2004 г., по инициативе России и других государств Генеральная Ассамблея ООН принимает резолюции, направленные на борьбу с фашизмом и национализмом. Последняя принята 18.12.2014 г. и называется «Борьба с героизацией нацизма, неонацизмом и другими видами практики, которые способствуют эскалации современных форм расизма, расовой дискриминации, ксенофобии и связанной с ними нетерпимости» [8]. Соавторами этого международного акта стали в общей сложности 44 государства. В резолюции выражается глубокая озабоченность по поводу прославления нацизма в любой форме и бывших членов организации «Ваффен CC», а также попыток объявления коллаборационистов участниками национально-освободительных движений. Резолюция предусматривает принятие соответствующих мер на национальном уровне, в том числе и законодательных.
В мае 2014 г. в России была введена уголовная ответственность за реабилитацию нацизма и несколько человек уже были осуждены в соответствии с законом. Аналогичные нормы содержатся и в законодательстве многих других стран. Например, в августе 2019 г., после того как в поселке Моглино Псковской области было обнаружено массовое захоронение узников концентрационного лагеря, находившегося во Время Великой Отечественной войны на данной территории. Сотрудниками Следственного комитета Российской Федерации (далее по тексту - СК РФ) было возбуждено уголовное дело по ст. 357 (Геноцид) УК РФ. Сотрудники ведомства указали на то, что были обнаружены останки 46 человек, смерть которых наступила в результате огнестрельного ранения в голову. Информация по данному расследованию была рассекречена ФСБ в июне 2019 г.

Отметим, что расследование Моглинского дела было начато еще в 60-е гг. ХХ в. К 1965 г. следствием была установлена судьба всех 34 охранников Моглинского лагеря: часть из них умерла, кто-то проживал за границей. В связи с наступлением политики проведения «холодной войны» получить более точные сведения правоохранительным органам СССР не представлялось невозможным. В тот период времени наказание было вынесено только в отношении 4 человек: 22.09.1967 г. судебная коллегия Псковского областного суда постановила приговорить к высшей мере наказания 3 человек и 1 человек был приговорен к 10 годам лишения свободы в колонии строгого режима, поскольку на момент совершения преступления он был несовершеннолетним.

В настоящее время СК РФ расследует преступление без срока давности: казнь 214 детей в детском доме г. Ейска Краснодарского края в 1942 г. Палачи 9 и 10 октября 1942 г. убили воспитанников в газвагенах, их трупы сбросили в общую яму и закопали. Забирали их из детского дома партиями, рассказывая, что их везут на лечение, в баню, грузить семечки.

Одним из палачей следствие считает Г. Оберлендера, который числился в Зондеркоманде CC-10 «а» переводчиком. Когда стало известно о его преступлениях в годы войны, в декабре 2019 г. решением ВС Канады он был лишен гражданства, т.к. скрыл от властей свое участие в карательном подразделении.

«В рамках расследования уголовного дела о 
геноциде в октябре 1942 г. воспитанников детского дома г. Ейска ГСУ СК РФ направило запрос о правовой помощи в компетентные органы Канады с просьбой предоставить документы уголовных дел и иных судебных процессов в отношении Г. Оберлендера»,- рассказали в СК РФ [12].

Президент Российской Федерации В.В. Путин в обращении к участникам Международного научно-практического форума «Уроки Нюрнберга» от 20.11.2020 г. в очередной раз указал на важность уроков Нюрнберга, необходимых для того, чтобы бороться с искажениями и фальсификаций событий Второй мировой войны, особенно - с лживым попытками реабилитировать и даже возвести в звание героев нацистских преступников. Глава государства также отметил, что на настоящий момент в России продолжается процесс рассекречивания архивных документов, работа поисковых команд с целью расследования и раскрытия неизвестных, но, без сомнения, страшных преступлений прошедшей войны [15].

Подводя итоги всему вышесказанному, можно сделать вывод о том, что в развитии законодательства о преступлениях против человечества Российская Федерация играла и играет одну из ключевых ролей. Благодаря тому вкладу, который внес Советский Союз в Нюрнбергский Международный Трибунал, на международной арене до настоящего времени не теряют свою актуальность вопросы, связанные с криминализацией преступлений против человечества в качестве превентивной меры против подобного рода преступлений.

\section{Литература}

\section{Нормативные правовые акты:}

1. Договор об отказе от войны в качестве орудия национальной политики (Пакт Бриана-Келлога) // Сборник действующих договоров, соглашений и конвенций, заключенных СССР с иностранными государствами.1930.- Вып. V.- С. 5-8.

2. Декларация об ответственности гитлеровцев за совершаемые зверства от 30.10.1943 г. // Внешняя политика Советского Союза в период Отечественной Войны. Документы и материалы. Т. 1. М.: Государственное издательство политической литературы.-1944.- С. 363-364.

3. Устав Международного военного трибунала для суда и наказания главных военных преступников европейских стран оси от 08.08.1945 г. // Сборник действующих договоров, соглашений и конвенций, заключенных СССР с иностранными государствами.-1995.- Вып. ХI.-М.-С. 165-172.

4. Конвенция о предупреждении преступления геноцида и наказании за него от 09.12.1948 г. // Сборник действующих договоров, соглашений и конвенций, заключенных СССР с иностранными государствами.1957.-Вып. XVI.-М.- С. 66-71.

5. Конвенция о неприменимости срока давности к военным преступлениям и преступлениям против человечества от 26.11.1968 г. // Международная защита прав и свобод человека. Сборник документов.- М.: Юридическая литература, 1990.- С. 658-661.

6. Принципы международного сотрудничества в отношении обнаружения, ареста, выдачи и наказания лиц, виновных в военных преступлениях и преступлениях против человечества // Сайт Организации Объединенных Наций [Электронный ресурс]. URL: https://www.un.org/ru/documents/decl_conv/conventions/ warcrimes_principles.shtml (дата обращения: 19.04.2021 г.)

7. Документ СССР-93 из официального доклада, подготовленного польским правительством для международного военного трибунала // Нюрнбергский процесс, сборник документов [Электронный ресурс]. URL: https:/cont.ws/@ralexd/930612 (дата обращения: 20.04.2021 г.).

8. Резолюция, принятая Ассамблеей ООН от 17.12.2014 г. «Борьба с героизацией нацизма, неонацизмом и другими видами практики, которые способствуют эскалации современных форм расизма, расовой дискриминации, ксенофобии и связанной с ними нетерпимости» // Организация Объединенных наций [Электронный ресурс]. URL: https://undocs.org/ru/A/RES/69/160 (дата обращения: 18.04.2021 г.).

\section{Юридическая литература:}

9. Нюрнбергский процесс: Сборник материалов. В 8 т. Т. 1.- М.: Юридическая литература, 1999.- 762 с.

10. Орлов Д. Закулисье процесса века / Д. Орлов // Дилетант. - 2020.- № 4. - С. 14-17.

11. Федотов О. Процесс в цифрах и фактах / О. Федотов // Дилетант. - 2020. - № 4. - С. 18-19. 


\section{Электронные ресурсы:}

12. В Канаде суд отказал Оберлендеру в приостановке дела // РИА Новости [Электронный pecypc]. URL: https:// ria.ru/20210406/oberlender-1727108777.html (дата обращения: 29.05.2021 г.).

13. Международный трибунал по военным преступлениям в Руанде приговорил к пожизненному заключению бывшего полковника армии Руанды Теонесте Багасору // Би-би-си [Электронный ресурc]. URL: http://news. bbc.co.uk/hi/russian/international/newsid_7789000/7789524.stm (дата обращения: 29.05.2021г.).

14. Международный уголовный суд вынес первый в своей истории вердикт // Право.ру [Электронный ресурс]. URL: https://pravo.ru/interpravo/news/view/69863/ (дата обращения: 29.05.2021 г.).

15. Обращение к участникам форума «Уроки Нюрнберга» // Официальные сетевые ресурсы Президента России [Электронный ресурс]. URL: http://www.kremlin.ru/events/president/news/64447 (дата обращения: 21.05.2021 г.).

16. Отрицание отрицателей. Как в России и Европе наказывают за реабилитацию нацизма // Медиазона [Электронный ресурс]. URL: https://zona.media/article/2017/04/25/denial (дата обращения: 25.05.2021 г.). 